\title{
Discovering Knowledge and Cognitive Based Drivers for SMEs Internationalization
}

\author{
Jamshid Alinasab ${ }^{1}$. Seid Mohammad Reza Mirahmadi ${ }^{2}$ Hassan Ghorbani ${ }^{1}$. \\ Francesco Caputo ${ }^{3}$
}

Received: 1 March 2021 / Accepted: 30 May 2021 / Published online: 19 July 2021

(c) The Author(s) 2021

\begin{abstract}
Internationalisation begins with companies' decision to enter global markets to develop knowledge and experience as key competitive factors in the global economy, which has been the subject of much empirical research. Decision-making, knowledge management, and effective internationalisation have become key strategic tools for all companies, especially for small- and medium-sized enterprises (SMEs). This study wants to provide a framework for SMEs internationalisation based on the real options theory, (ROT) as a knowledge driver method. For this purpose, the effective factors for internationalisation were identified by reviewing the literature on the subject and the internal and external backgrounds of the subject. Then, main and subfactors were prioritised by the fuzzy analytic hierarchy process (AHP) method. The statistical population consisted of senior managers, business managers of SMEs in Isfahan, Iran, who were eligible to enter this study. Twenty-six experts participated in this study by judgmental non-random sampling method. A fuzzy AHP questionnaire was prepared in the form of 19 sub-factors and 7 main factors. The components of each factor in each group were also ranked by experts, and their weights were obtained. Next, according to the ROT strategies which have 5 options, an alignment matrix was used to align the factors affecting the decision with the strategies. After answering the research question, the option that had a higher mode was considered $A S$; then, this score was multiplied by the weight obtained in the previous step and the TAS was obtained. Finally, strategies were classified as appropriate, need further investigation, and inappropriate.
\end{abstract}

Keywords International market entry $\cdot$ Internationalisation $\cdot$ Real options theory · $($ ROT) $\cdot$ Decision-making $\cdot$ Small and medium sized enterprises (SMEs)

This article is part of the Topical Collection on Enhancing the Adaptability of Family Businesses to the Knowledge-based Economy

Francesco Caputo

francesco.caputo2@unina.it

Extended author information available on the last page of the article 


\section{Introduction}

Subjectivity, complexity, and uncertainty are relevant challenges to face in decisionmaking processes. A large segment of guidelines for the definition of efficient and effective approaches in decision-making processes have been defined as a consequence of the diffusion and understanding of specific social and economic dynamics (Calabrese et al., 2018). Managerial, marketing, and organisational studies have started to investigate the ways in which managers can support decision-makers and organisations in gaining a better understanding of and managing the emerging complexity (Caputo \& Evangelista, 2019).

The term internationalisation in research fields has various definitions that can be defined as a gradual process of promoting and strengthening the actions and activities of a company abroad (Johanson \& Vahlne, 1977) or as an increasing external movement in the direction of international actions by one or a group of companies (Welch \& Luostarinen, 1988). The term internationalisation in most contexts usually refers to the process of increasing participation and involvement in international actions in which the company's activities and performance in terms of explaining the strategy, determining the structure and use of resources, or developing networks of business relations in foreign markets are solely subject to adaptation to international environments (quoted by Pham, 2019). Del Giudice et al. (2017) explained that high informal institutional distance leads to a preference for non-equity-based collaborative entry mode by SMEs. They also defined that positive time trends of the host country, positive perception of size, and resource of the local partner, as well as the local partners' power, lead to a preference of equity-based collaborative entry mode by SMEs. Research shows that companies seeking to internationalise must have a strong organisational structure in line with their foreign activities and actions. In addition, they need to gain an accurate and comprehensive understanding of the many advantages and disadvantages that may exist in different ways of entering foreign markets (Laufs \& Schwens, 2014).

Market characteristics, cultural understanding, and knowledge management significantly affect management behaviour, while they do not significantly affect the Internationalisation strategy. Furthermore, management behaviour significantly affects Internationalisation strategy and can mediate relationships between market characteristics, cultural understanding, and knowledge management with Internationalisation strategy (Nurcholis, 2020). Knowledge has increasingly established itself as an asset to be acquired and has valued for the achievement of a competitive, lasting and defensible advantage by companies. Knowledge management in particular is considered as one of the disciplines supporting the formulation and the implementation of successful strategies. The theme of knowledge has been the subject of countless reflections ranging from philosophy to economics (Canestrino \& Magliocca, 2019).

In general, the ability to become international has become a necessity and a must for many companies, which makes both the survival and growth of the company in the field of globalisation (Raymond \& St-Pierre, 2011) and a knowledge-based economy possible. The multidisciplinary character and the 
affirmation of multiple approaches to the analysis of the processes of creation and management of knowledge have led to an effort of systematisation, which from the analysis of interpretative paradigms of knowledge and knowledge management reaches examination of the most recent conceptual elaborations on Knowledge Ecosystems (Canestrino \& Magliocca, 2019). Moreover, Canestrino and Magliocca (2016) define internationalisation as transferring knowledge through Cross-Border Communities of Practice $(\mathrm{CCoP})$ which is used as a way for managing knowledge in a global socio-economic environment. It is mainly referring to the rising economies and explains that with reference to both the opportunities and challenges that characterise the rising economies. CCoP arises as the best suitable way to transfer knowledge at the international level, when firms from developed countries encounter firms from emerging countries.

The process of internationalisation in SMEs is based on a learning process and requires a set of capabilities (Schweizer, 2012). Its impact has also been proven as one of the most important sources of corporate growth and performance improvement in many documents in the field of international trade and business (quoted by Joensuu-Salo et al., 2018). Dell'Anno et al. (2018) believe that the phenomena of Internationalisation involve every type of organisation: private and public, forprofit, and non-profit, and large and small; therefore, international start-ups by the accumulated knowledge stemming from the relationship between knowledge and internationalisation are able to identify the main factors influencing the choice of the market on the part of the knowledge-based firms. Hence, knowledge-based entrepreneurship as a virtuous combination of knowledge and entrepreneurship enables start-ups and SMEs to boost capacities for such expansion of firms originating from innovation and that have operations suited to a widely ultra-national context.

The important point is that SMEs must consider the nature of the industry in question, the risk of producing and delivering non-tradable goods and services, the nature of their support systems as a source of knowledge, and the potential impact of rapid change in an internationally competitive environment. (Quoted from Gao et al., 2019). To define SMEs in the form of family enterprises, institutions with personal and cooperative ownership, or formal and informal companies, several factors have been considered. It includes the number of employees, amount of income such as annual turnover, years of activity in the field of business, and number of branches and locations (Khaidher et al., 2019). Factors and components affecting the success of SMEs in different countries have been studied by researchers, and depending on the conditions, several indicators have been mentioned by them. In this regard, Chawla et al. (2010) in their studies have concluded that small businesses in China are influenced by factors related to marketing, competitive forces, location, industry trends and trends, location, availability capital, and experience of the owner. Innovation and information technology (IT) are critical to effective knowledge management (KM). So, that increasing the level of IT can enhance SME's internationalisation. SMEs are able to heighten their innovation by implementing comprehensive ERP and E-CRM which leading to higher export intensity as the primary method of internationalisation (Lecerf \& Omrani, 2020). Caputo et al. (2020) have recognised internationalisation as one of the more recently debated topics in the management 
field and explained the influence of international R\&D teams on companies' innovativeness.

By examining the studies conducted in this field, we can point two factors such as the benefits of internationalisation and the conditions of the target market and the destination country and the characteristics of the industry, country of origin, convergence, and adherence factor, organisation conditions. In an effort to organise SMEs internationalisation decision-making practices, Child and Hsieh (2014) proposed four models that SMEs leaders should follow. These models range from high to low levels of planning and rationality, which include reactivity, multiplicity, limited rationality, and reasoning of real choices. This approach is the highest form of rational decision-making in Child and Hsieh (2014) model, which is defined as the ability of managers to identify, maintain, and exploit real options in the business environment in which they operate (Driouchi And Bennett, 2011). The real option is a specific type of investment (in the international arena) in something of value with uncertain achievement and feedback (for example, joint ventures and investments in R\&D units elsewhere). This type of decision implies that companies need to minimise their current investment when the level of uncertainty is high; however, still consider an option to invest at other times and in situations where uncertainty is expected to be lower (Brouthers et al., 2008, citing Ahi et al., 2017). Postponement or staging, growth, scaling, shifting, and releasing strategic investment choices are real options (quoted in Trigeorgis \& Reuer, 2017). In the present study, the aim is the priority and importance of effective factors and criteria in decision-making to enter a new market and the degree of alignment with each of the decision options based on ROT. Accordingly, research questions include the following:

- What are the priorities and importance of influencing factors and criteria in deciding to enter a new market?

- Which of the main decision factors for entering the international market corresponds to which of the decision options based on the ROT?

\section{Theoretical Literature of Research}

\section{Factors Influencing the Decision to Enter International Markets}

SMEs are different from other large companies due to their smaller size, limited resources, and capabilities, as well as organisation systems and structures. According to Papadakis and Barwise (2002), it is expected that smaller companies will have less formal and rational decision-making processes. The perceived gaps in respect of using traditional decision support systems point to the growing need for a shift to more advanced and sophisticated technological solutions (Kaur et al., 2019). Some other aspects that make small companies different from big companies are that such companies use a higher degree of insight (insight and intuition) in their decisions (Khatri and $\mathrm{Ng}, 2000$ ), there is less focus on the comprehensive information collection (Gilmore et al., 2001), and senior management/leaders have a stronger influence on the decision-making process (Elbanna \& Child, 2007). 
Casali and Perano (2020) have defined synthesise and critique the voluminous, multidisciplinary literature on factors influencing ethical decision making (EDM), and shown that there are up to 42 potentially influencing factors on EDM in the literature. The most important factors that may influence the decision-making of SMEs are (i) information scarcity (Gabrielsson \& Gabrielsson, 2013); (ii) resource availability (Evers \& O'Gorman, 2011); (iii) characteristics related to decisionmaking leadership, and their interpretation of the environment (Child \& Hsieh, 2014); (iv) knowledge and the previous experience of the entrepreneur and social and business networks (Evers \& O'Gorman, 2011); and (v) the structure of hybrid governance in SMEs in which the business model is normally aligned with the partners. This suggests that the decision-making process (Nummela et al., 2014), like goal setting (Gabrielsson \& Gabrielsson, 2013), is shared with partners.

Moreover, some small companies, such as larger organisation, have well-designed routine procedures, and decisions may be made based on existing management knowledge (quoted in Ahi et al., 2017). According to the theory of top management, organisations are a reflection of their senior management teams, and decisions at the company level such as internationalisation depend to a large extent on the background and experience of the team, their experience, and values (Hiebl, 2014). Managers must have the knowledge to enable them to process and analyse information effectively and efficiently in a complex and uncertain process such as internationalisation (Ramón-Llorens et al., 2017). In a way, it can be said that decisions are influenced by managers' cognitive-mental schemes that are based on their academic and functional backgrounds, experiences, views, values, and demographic characteristics (Hiebl, 2014). In a general framework, situations are interpreted differently, and actions are taken, and accordingly, the company's achievements are the result of the composition of senior management teams (quoted by Alayo et al., 2019).

In an international strategy, the entry mode chosen by the companies has profound important strategic consequences in terms of the way in which it conditions, the level of control of the operations, and immobilisation of company resources in the markets. As a result, firms adopt this decision as rationally as possible becomes vital, looking for the highest success level in the market within which they choose to operate (De Soto-Camacho \& Álvarez-Torrescusa, 2018). When companies decide to internationalise their operations, they must choose the appropriate entry mode in foreign countries. This decision greatly affects the organisational and operational aspects related to their international development. Companies often have to deal with alienation (Wu \& Salomon, 2016) due to a lack of information about the local business environment, including administrative and political systems, as well as social and cultural factors.

International SMEs are responsive to the prevalent social problems if the local government supports their business development. And the greater local government support, along with network competencies, provides resource accessibility to international social enterprises (Scuotto et al., 2020). To understand this phenomenon, previous studies have introduced the concept of distance to obtain differences between host and guest countries. This concept is mainly used to objectively assess the degree of dissimilarity between countries or to examine the decision-maker's 
perception of incompatibility from a mental perspective (Ambos \& Håkanson, 2014). In addition, the greater the psychological distance between the host and host countries, the greater the level of uncertainty for companies wishing to expand international operations. Hence, distance is considered a major challenge and obstacle for international activities and leads to increased complexity.

Cultural Distance This concept depicts the differences between the cultural values of the two countries and is the most widely used dimension of distance (Beugelsdijk et al., 2018). Individualism versus collectivism, distance from power, avoidance of uncertainty, masculinity versus women-centeredness, long-term approaches versus short-term orientation, and cohesion versus constraint are among the factors for determining distance. Schwartz (1994) developed new cultural dimensions and summarised them in three bipolar dimensions: confinement versus independence, egalitarianism versus hierarchy, and harmony versus domination.

The Distance of Administrative or Executive Approaches Administrative distance, which is also called political distance, can be defined in the form of various characteristics; existence of colonial ties, economic, monetary, or political unions, political hostility, government policies, and institutional weaknesses. This concept mainly refers to the historical, institutional, and political components, and unlike the cultural distance, this dimension of the distance studied by experimental research is relatively small and therefore difficult to evaluate. The presence of colonial backgrounds leads to a better understanding of the target market and possibly reduces uncertainty. Conversely, political hostility or political risk, in general, may make it more difficult to access the market, thus increasing the degree of uncertainty in the country in question. Dow and Karunaratna (2006) state that differences and contradictions in political systems between two countries increase the costs and risks associated with entering a foreign market and may therefore influence the market selection process. Differences in institutional environments can also increase the degree of uncertainty of foreign companies. The findings of Pattnaik et al. (2014) show that the quality of institutions has a negative effect on lateral performance.

Geographical Distance The most obvious dimension is distance and often refers to the number of kilometres or miles that separates the country of origin from the host country. This dimension is also reflected in the form of travel time and costs such as coordination costs because differences in time zone can make coordination more difficult. These differences lead to uncertainty about the ability to communicate quickly in order to solve an immediate problem. Efficient knowledge transfer may also be affected (Ambos \& Ambos, 2009). Boeh and Beamish (2012) also state that physical separation influences strategically important decisions. Ragozzino (2009) highlights the role of geographical distance in decisions to enter foreign markets. He argues that proximity probably reduces information asymmetry and explains that companies located near their target markets may have access to information through business partners or stakeholders, thus reducing uncertainty about the host country's environment. 
Economic Distance Indicates the difference in economic wealth between the two countries or the difference in the quality and cost of natural, financial, and human resources. This type of difference at the economic level may be reflected in purchasing power, labour costs, macroeconomic stability, or the degree of openness of economies (Berry et al., 2010). Companies prefer countries with similar economic characteristics. In general, companies have started to expand and expand their activities to countries that are economically similar to other countries that are further economically distant in the next period (quoted by Moalla and Mayrhofer 2020) (Table 1).

\section{Real Option Theory}

Decisions in an organisation involve evaluating the options available to conclude the choice of action type (Elbanna \& Child, 2007). Decisions need to be made in an orderly manner; however, some decisions may be important to the organisation because of the impact on the company's strategic performance (Zheng et al., 2006). Such decisions are called strategic decisions. Therefore, strategic decisions are important for the organisation because their success can determine the overall success of the organisation (Sharma et al., 2014). Making decisions in its strategic form in the organisation is associated with the complexity of the process and uncertainty in various forms. However, these decisions play a much more critical role in the survival and performance of the organisation and involve senior leaders in the organisation (Sinclair \& Ashkanasy, 2005) and therefore can be the basis for decision-making throughout the organisation. The application of real options in the field of strategic management begins with the identification of existing options (shadow) that are derived from the company's previous strategic decisions and then will be accompanied by the identification of real options that can be achieved (through research and development, contracts, etc.). This step and evaluation of real options (valuation) are basically based on the competencies and capabilities of individuals. Based on the organisational and behavioural characteristics of a company, it has started to manage the portfolio of real options, which in turn will lead to more intuitive decisions (based on insight and insight) about using an option (Trigeorgis \& Reuer, 2017).

\section{Dimensions of Real Options}

For asset and project management, the types of real options according to the dimensions of flexibility and strategic use are growth options (opening new opportunities), learning options (learning about the market, customers, etc.), and guarantee options (goals related to risk management).

Regarding the real growth options, a given investment can be the basis for starting a chain of interconnected projects and thus pave the way for future growth prospects, new, strengthening core capabilities (implementation of new projects, new processes, market penetration) (Kester, 1984). Guaranteed options allow you to react to unfavourable demands and price changes in the form of cancellation as well as practical compatibility. In contrast to growth options, guaranteed options make it 


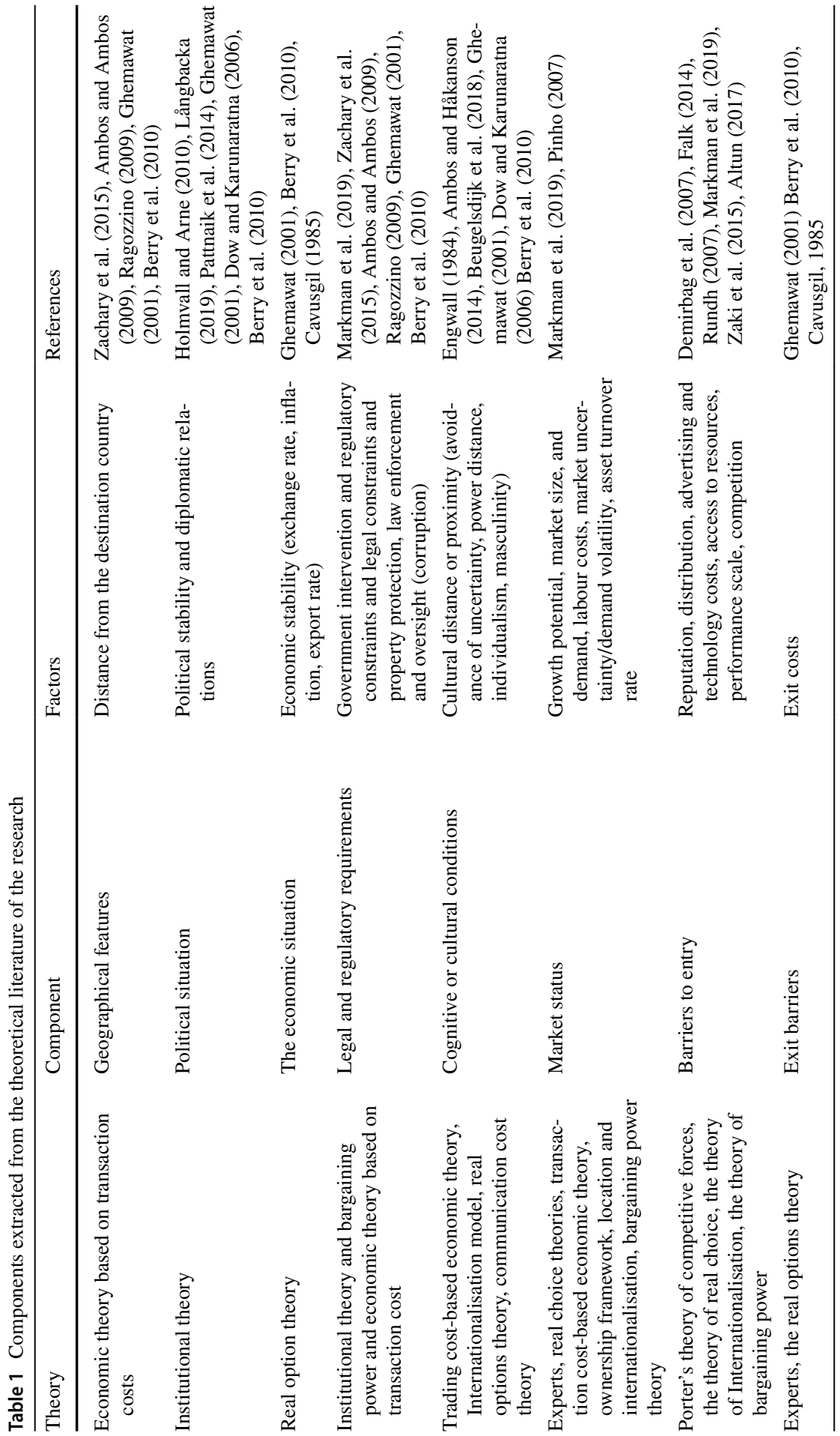




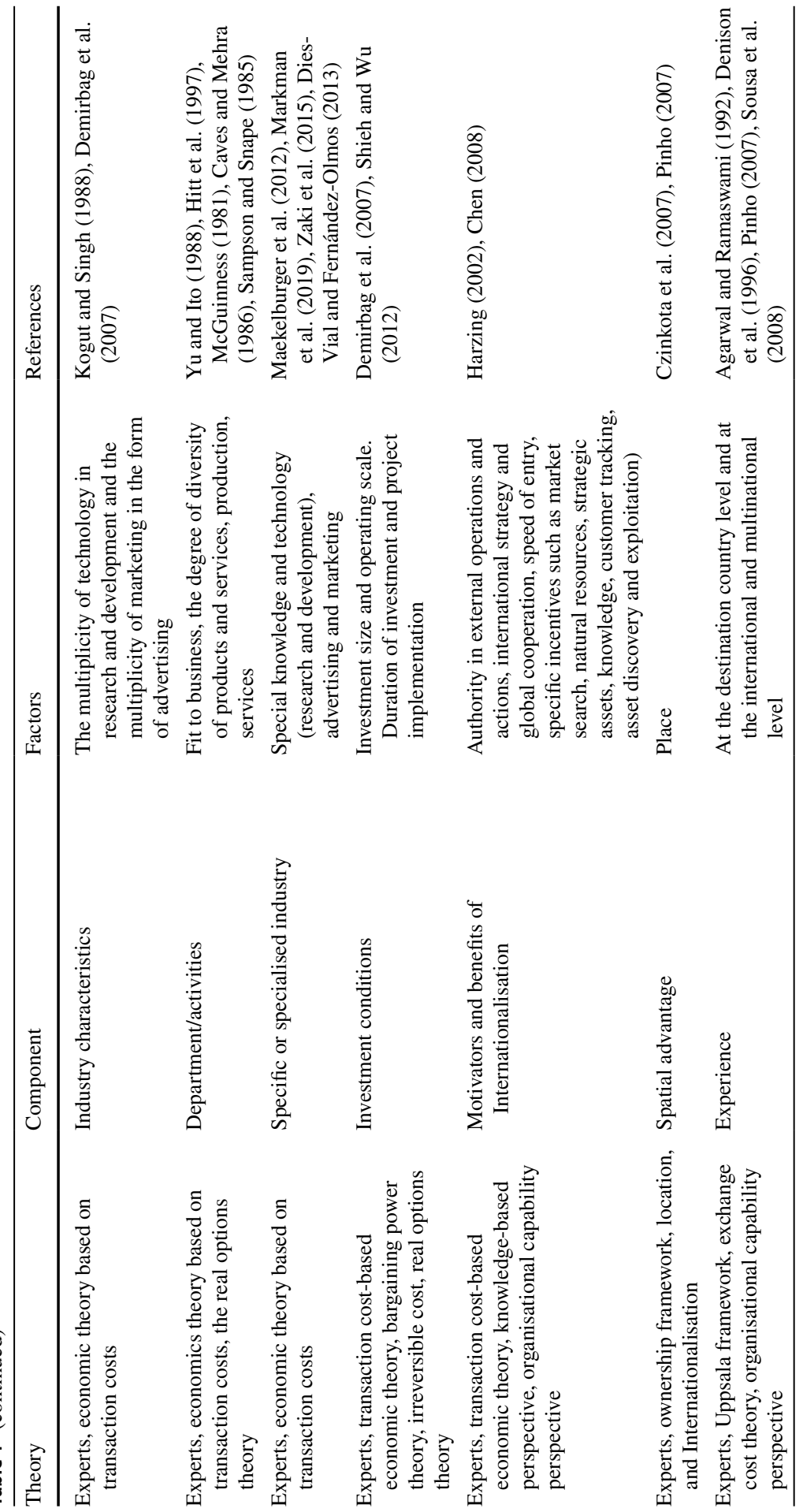




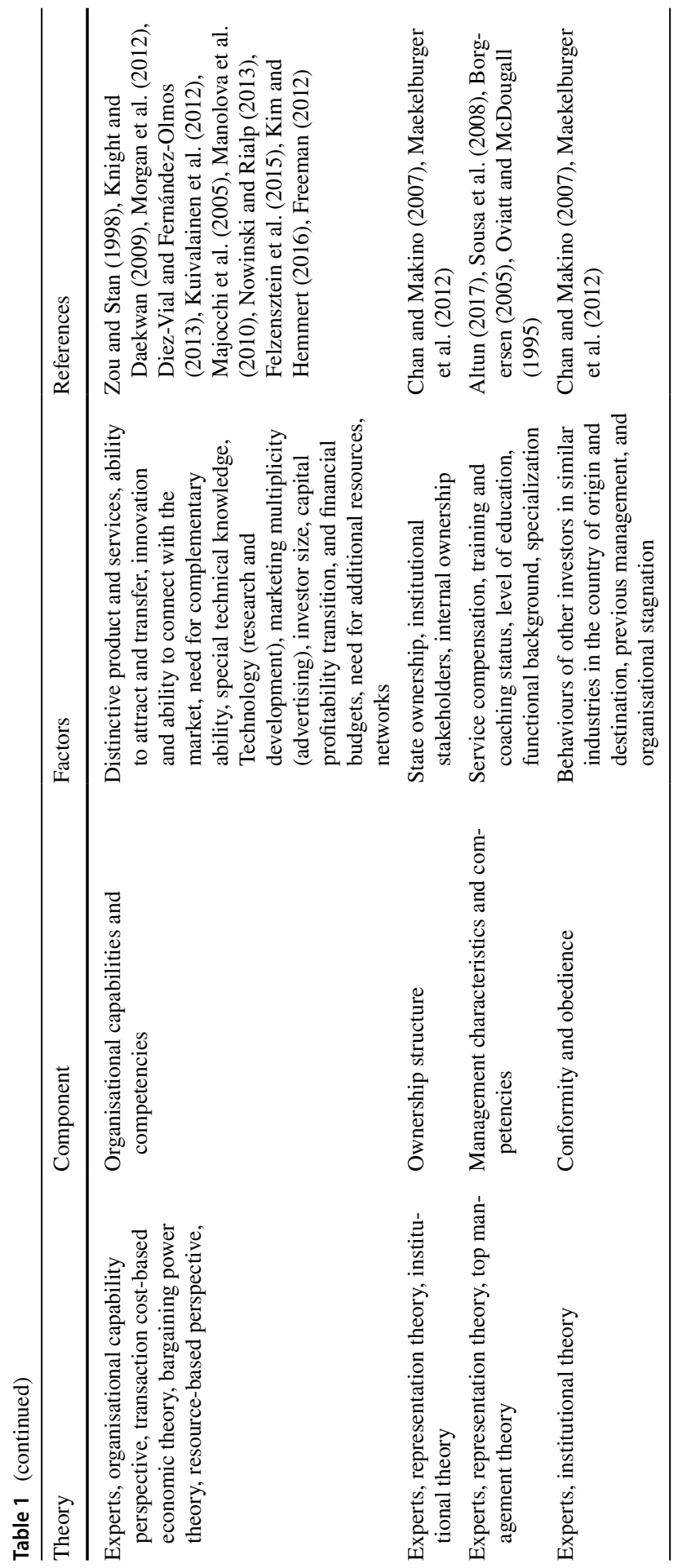


possible to protect the company against the risks associated with losses so that the company is able to avoid declining cash flow levels (Copeland \& Howe, 2021).

A real option in the form of learning makes the investment decision to postpone it or to reduce management risk and make irreversible decisions based on incomplete information and thus tolerate the adverse consequences of abandonment. In a way, it can be said that the more uncertainty and uncertainty about the decision, the more senior executives of the company prefer to delay the implementation of a project and keep the option to implement it in the future (to Quoted from Csapi, 2019) (Table 2).

\section{Research Method}

The research method in the present study has been, in terms of purpose, both developmental and applied research because the purpose of it is the development and improvement of methods, tools, goods, or structures and therefore is included in the category of developmental-applied research. The environment in which the research is conducted shows the background of the research, which may take three general modes: library research, field research, and experimental research. The data and information contained in this study were obtained from two different sources: (1) first-hand data obtained from interviews and observations and (2) second-hand data obtained from related articles, documents, and documents. The technique employed to collect data is the semi-structured interview (Fife, 2005), which enables participants to discuss the business realm with a researcher (Behar, 2014) and to highlight personal thoughts (Collins \& Cooper, 2014), even when emotions and/ or external inputs may cause some misunderstandings (Hawamdeh \& Raigangar, 2014). Therefore, the present research will be considered as library-field research. Sarmad believes that research is divided into two categories based on how data is collected: descriptive research and experimental research. The present study is classified, based on nature and method, in the survey group. Also, based on the type of data and the industry under study, it can be considered as a case study.

Table 2 Strategic investment selections as real options (Trigeorgis \& Reuer, 2017)

\begin{tabular}{ll}
\hline A: Real basic options & \\
\hline Option type & Investment selection/description \\
\hline Defer or stage & Delay or stage market entry when facing demand uncertainty \\
Growth & Enter new or foreign market (with option to buy partner) \\
Alter scale (expand/contract) & Expand or contract plant or scale of outsourcing contract \\
Switch & Switch suppliers or production across foreign subsidiaries \\
Abandon/exit & Exit market (or sell technology for salvage) if conditions deteriorate \\
\hline
\end{tabular}




\section{Statistical Population}

The statistical population of the present study consists of senior managers and business managers of SMEs in Isfahan, Iran, who are eligible to enter this study. Conditions for entering the research are export experience, being in the process of entering the international market, or present in the international market. The samples of SMEs operated in different sectors and shared similarities and differences in their business operations.

\section{Statistical Sample, Sampling Method, and Design}

The number of the members who express the main characteristics of the community are called "statistical samples." In this study, a purposive or judgmental non-random method was used for sampling. Thus, as per the given guidelines, we interviewed 26 executives who are working in SMEs in Isfahan. These executives occupy key positions in the organisation with decision-making powers in the firm. Our sample size of 26 executives also falls within the acceptable sample range for qualitative studies (15 being the minimum acceptable sample) (Guest et al., 2006).

The executives who participated are holding key positions and are eligible to provide firm insights into the potential factors of internationalisation. Criteria for selecting experts were theoretical mastery, practical experience, willingness, and ability to participate in research and accessibility. Like any other type of sampling, the sample size depends on factors such as accessibility, required time, and data collection costs (Table 3).

\section{Methods and Tools of Data Collection}

The main methods of data collection in this research are library studies and field research. Collection of information has been employed in the field of theoretical foundations and research literature by library resources, articles, books, publications, and the internet. For field research, a questionnaire was used to collect data in the practical part, and in the quantitative part, in order to prioritise and weigh

Table 3 Research and community stages and sample of experts

\begin{tabular}{lll}
\hline Steps & Population & Number \\
\hline Fuzzy AHP Questionnaire & $\begin{array}{l}\text { Industry experts in small and medium sized } \\
\text { enterprises in Isfahan with internationalisation } \\
\text { experience }\end{array}$ & 26 people \\
Alignment matrix & $\begin{array}{l}\text { Industry experts in small and medium sized } \\
\text { enterprises in Isfahan with internationalisation } \\
\text { experience }\end{array}$ & 26 people \\
\hline
\end{tabular}


Table 4 Factors

\begin{tabular}{|c|c|}
\hline Factors & Sub-factors \\
\hline $\begin{array}{l}\text { Country level (host) } \\
\text { determinants }\end{array}$ & $\begin{array}{l}\text { Geographic characteristics } \\
\text { Political situation } \\
\text { Economic (macro) situation } \\
\text { Regulatory and nominative (legal) conditions } \\
\text { Cognitive (cultural) conditions }\end{array}$ \\
\hline $\begin{array}{l}\text { market level determi- } \\
\text { nants }\end{array}$ & $\begin{array}{l}\text { Attractiveness } \\
\text { Entry/exist barriers }\end{array}$ \\
\hline Industry specificity & $\begin{array}{l}\text { Industry assets specificity } \\
\text { Investment condition }\end{array}$ \\
\hline $\begin{array}{l}\text { Motivation interna- } \\
\text { tionalisation }\end{array}$ & Motivation internationalisation \\
\hline $\begin{array}{l}\text { Firm-level determi- } \\
\text { nants }\end{array}$ & $\begin{array}{l}\text { Experience } \\
\text { Capabilities } \\
\text { Resources } \\
\text { Ownership structure } \\
\text { CEO characteristics }\end{array}$ \\
\hline $\begin{array}{l}\text { Conformity and } \\
\text { obedience }\end{array}$ & Conformity and obedience \\
\hline $\begin{array}{l}\text { Home country deter- } \\
\text { minants }\end{array}$ & $\begin{array}{l}\text { Cultural conditions } \\
\text { Economic conditions } \\
\text { Regulatory conditions }\end{array}$ \\
\hline
\end{tabular}

each factor and sub-factors with the help of the fuzzy analysis hierarchical process (AHP) technique, a questionnaire was designed as a pairwise comparison matrix. In this questionnaire, first, the main factors and then the sub-factors of each factor were compared separately in pairs (Table 4). According to Table 5, all extracted indicators were given.

Table 5 Fuzzy and non-fuzzy weights of the main factor

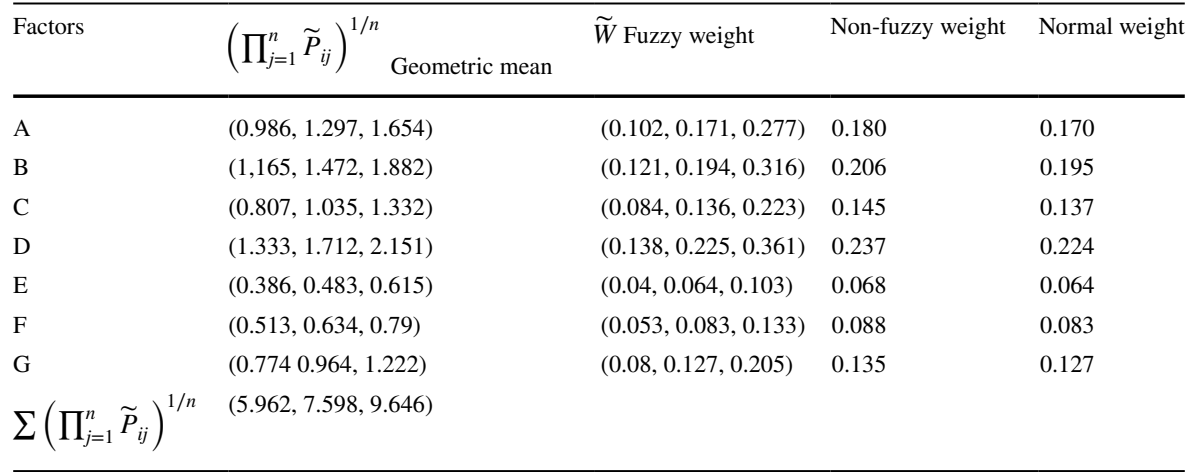




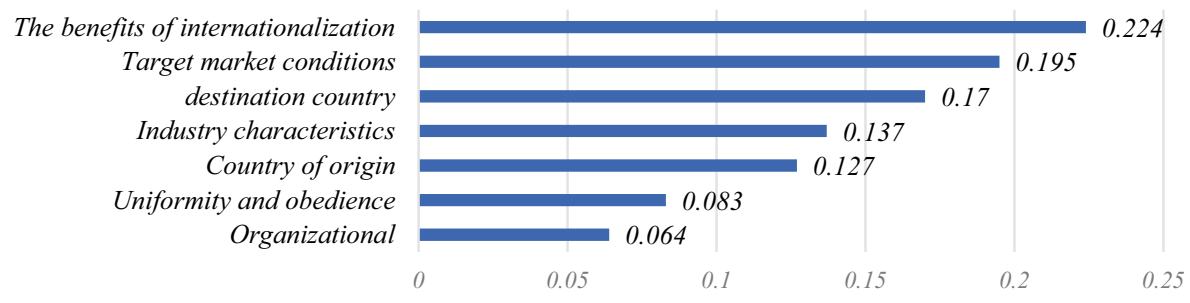

Fig. 1 Weights of the main factor

\section{Alignment Matrix}

In the third step, a matrix was formed for each factor to determine the decision options based on the ROT. The matrix rows are the main and sub-factors identified in the qualitative stage along with the weights calculated in the fuzzy AHP stage. The matrix columns determine the decision options. As mentioned before, in this study, based on the ROT, we have 5 decision options (strategies) that showed in the matrix to align the factors affecting the decision with the ROT.

\section{Information Analysis Results}

\section{Results of Fuzzy AHP Method}

In the previous step, research factors were identified and confirmed. In this phase, firstly, pairwise comparisons of factors are formed and provided to 26 respondents. After answering the pairwise comparisons, the incompatibility rates of the tables were calculated, all of which were $<0.1$. This proves that the stability and reliability of pairwise comparisons are acceptable; then, the answers were merged using the geometric mean method and merged in the form of pairwise comparisons. We calculated the priorities via the geometric means method of Buckley.

Table 6 Fuzzy and non-fuzzy weights of the sub-factor of the destination country

\begin{tabular}{lllll}
\hline Factors & $\left(\prod_{j=1}^{n} \widetilde{P}_{i j}\right)^{1 / n}$ Geometric mean & & \multicolumn{1}{l}{ Non-fuzzy weight } & Normal weight \\
\hline A1 & $(1.201,1.467,1.766)$ & $(0.187,0.276,0.402)$ & 0.285 & \\
A2 & $(0.52,0.629,0.761)$ & $(0.081,0.118,0.173)$ & 0.123 & 0.276 \\
A3 & $(1.101,1.322,1.585)$ & $(0.172,0.249,0.361)$ & 0.258 & 0.119 \\
A4 & $(0.557,0.674,0.812)$ & $(0.087,0.127,0.185)$ & 0.131 & 0.249 \\
A5 & $(1.015,1.217,1.486)$ & $(0.158,0.229,0.338)$ & 0.239 & 0.127 \\
$\sum\left(\prod_{j=1}^{n} \widetilde{P}_{i j}\right)^{1 / n}$ & $(4.394,5.309,6.411)$ & & & 0.230 \\
\hline
\end{tabular}




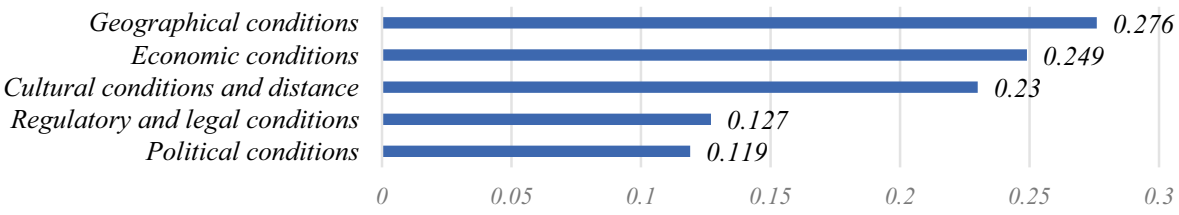

Fig. 2 Weights of sub-factor of the destination country

According to Fig. 1, the benefits of Internationalisation with a weight of 0.224 achieved first place. The target market condition with 0.195 was ranked second and the destination country with 0.17 was third. Industry characteristics, country of origin, uniformity, and obedience, and organisational factors were in the next positions, respectively. Therefore, in a similar way for other pairwise comparisons (sub-factor), these calculations are performed as follows (Table 6).

Regarding Fig. 2, among the sub-factors of the destination country, the geographical conditions with 0.276 have gained the first rank. Economic conditions with a weight of 0.249 ranked second and cultural conditions and distance with a weight of 0.23 ranked third. Regulatory and legal conditions, and political conditions were fourth and fifth in the ranking (Table 7).

In terms of Fig. 3, the attractiveness of the target market with a weight of 0.617 ranked first and the barriers to entry and exit of the market with 0.383 ranked second (Table 8).

According to the Fig. 4, investment condition with 0.504 ranked first, and then was the industry assets specificity with a weight of 0.496 (Table 9).

Regarding Fig. 5, the experience with a weight of 0.268 achieved the first place. The resources with 0.263 was ranked second and the capabilities, CEO characteristics, and ownership structure with the weight of $0.175,0.168$, and 0.126 are in the next, respectively (Table 10).

According to Fig. 6, among the sub-factors of the country of origin, the cultural conditions of the country of origin with a weight of 0.341 have gained the first place. Economic conditions with 0.340 ranked second, and legal regulatory conditions was 0.318 .

Table 7 Fuzzy and non-fuzzy weights of the target market factor

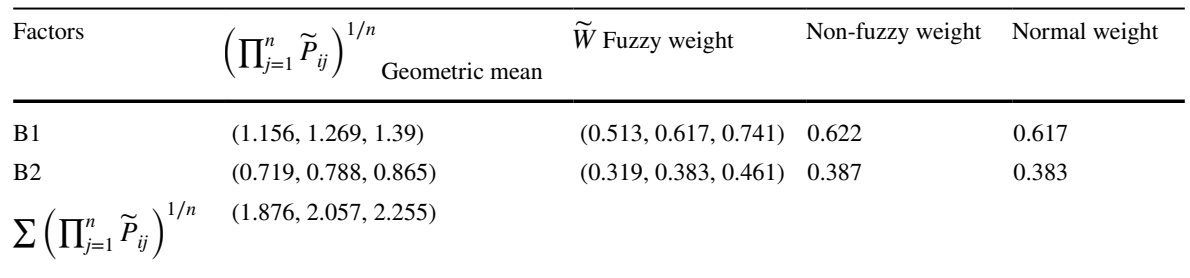




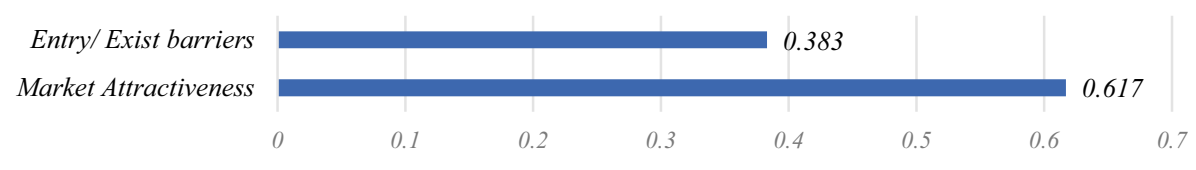

Fig. 3 Weights of the target market sub-criteria

\section{Summary of Factor and Sub-factor Weights}

Table 11 summarises the weight and rank of the factors and sub-factors.

According to the results of Table 11, motivation internationalisation was the first. Then, market-level determinants, country-level (host) determinants, and industry specificity were $2 \mathrm{nd}, 3 \mathrm{rd}$, and 4 th, respectively. Home country determinants located fifth and after that was conformity and obedience, while firm-level determinants ranked 7th.

Based on the third step and in order to answer the research question, the experts were asked to rate the decision options between -2 and +2 , and the answer that has a higher fashion was considered as a score and this score in the weight obtained in the previous stage is multiplied before and the final result is obtained. Finally, we consider the positive options as the appropriate option, the zero-one is considered as the option needed for further investigation, and the negative score is the inappropriate option.

With reference to Table 12, after calculating the weight of each factor and determining the mode of scores given (AS) to each option for each factor using the opinion of experts (between -2 and +2 ), the final score of each criterion was obtained by multiplying these two numbers (AS * Total weight of each factor $=$ TAS). The inappropriate option is negative and in red, green is the appropriate option, and yellow is the option that cannot be commented on now and needs further investigation. The results are described below.

\section{Discussion and Conclusion}

\section{What are the Priorities and Importance of Influencing Factors and Criteria in Deciding to Enter a New Market?}

It was used to determine the ranking of factors in terms of experts and the fuzzy AHP technique in this field. Advantages of internationalisation and target market

Table 8 Fuzzy and non-fuzzy weights of industry specificity factor

\begin{tabular}{|c|c|c|c|c|}
\hline Factors & $\left(\prod_{j=1}^{n} \widetilde{P}_{i j}\right)^{1 / n} \quad$ Geometric mean & $\widetilde{W}$ Fuzzy weight & Non-fuzzy weight & Normal weight \\
\hline $\mathrm{C} 1$ & $(0.872,0.991,1.134)$ & $(0.382,0.495,0.646)$ & 0.505 & 0.496 \\
\hline $\mathrm{C} 2$ & $(0.882,1.01,1.147)$ & $(0.387,0.505,0.654)$ & 0.512 & 0.504 \\
\hline
\end{tabular}




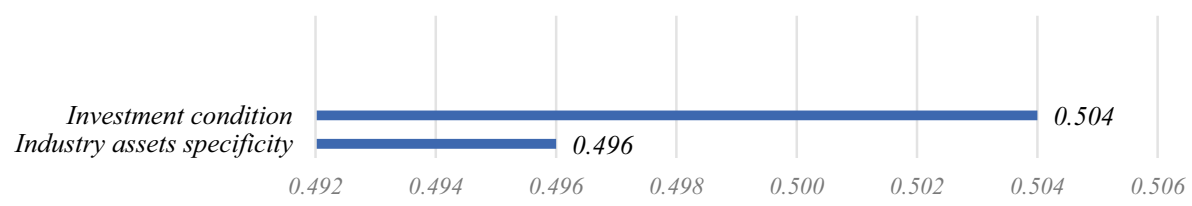

Fig. 4 Weights of industry characteristic sub-criteria

conditions and the destination country and industry characteristics are ranked first to fourth, respectively. Country of origin, conformity, and compliance factor, organisational conditions are ranked fifth to seventh, respectively. The sub-factors of each category were also ranked in the same category. The sub-factors of target market level determinants are the attractiveness of the target market in the first place and the barriers to entry and exit to the market in the second place. In the destination country, geographical conditions rank first, economic conditions rank second, cultural conditions and distance rank third, regulatory and legal conditions rank fourth, and political conditions rank fifth. The sub-factors of industry characteristics, investment conditions ranked first, and industry-specific characteristics ranked second. The subfactors of the home-country determinants, the cultural condition was first, the economic condition was ranked second, and the legal regulatory condition was in third place. Regarding the sub-factors of firm-level determinants, the experience was first, the financial condition of the company located second, organisational capabilities ranked third, and CEO characteristics ownership structure were in next levels.

Since no similar study has been conducted to rank these factors, comparison with previous research is not possible. In explaining the present findings, it can be said that internationalisation has benefits and incentives. At first glance, companies are looking to enter the international market to gain these benefits. But to rape these benefits, the target market conditions must be properly examined to see if the product or service in question is needed in this country. Is there growth potential? What are the barriers to entry and exit from the market? Then the geographical, economic, cultural, political, and legal suitability of the destination country for entry must be examined because if the destination country is fluctuating economically or there

Table 9 Fuzzy and non-fuzzy weights of organisational sub-factor

\begin{tabular}{|c|c|c|c|c|}
\hline Factors & $\left(\prod_{j=1}^{n} \widetilde{P}_{i j}\right)^{1 / n} \quad$ Geometric mean & $\widetilde{W}$ Fuzzy weight & Non-fuzzy weight & Normal weight \\
\hline E1 & $(1.171,1.395,1.651)$ & $(0.19,0.268,0.375)$ & 0.275 & 0.268 \\
\hline E2 & $(0.77,0.911,1.081)$ & $(0.125,0.175,0.246)$ & 0.180 & 0.175 \\
\hline E3 & $(1.164,1.371,1.617)$ & $(0.189,0.263,0.367)$ & 0.271 & 0.263 \\
\hline E4 & $(0.554,0.655,0.775)$ & $(0.09,0.126,0.176)$ & 0.129 & 0.126 \\
\hline E5 & $(0.742,0.877,1.037)$ & $(0.12,0.168,0.236)$ & 0.173 & 0.168 \\
\hline$\sum\left(\prod_{j=1}^{n} \widetilde{P}_{i j}\right)^{1 / n}$ & $(4.4,5.208,6.161)$ & & & \\
\hline
\end{tabular}




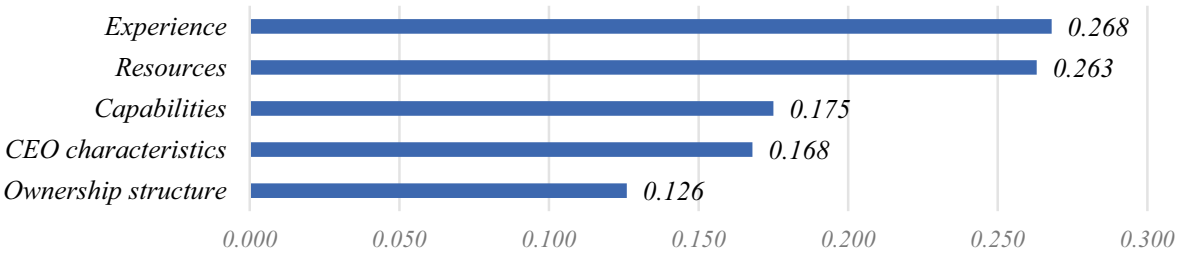

Fig. 5 Weights of organizational sub-criteria

are political restrictions with the country of origin, the companies will definitely face problems in continuing their work. Also, some industries have special features that require high costs, special technology, and high capital requirements. The more these features are, the more research needs to be conducted to enter the international market. In the next step, the conditions of the home country such as economic conditions and regulatory conditions could be important factors in deciding to enter the international market. In particular, cultural conditions such as risk-taking and economic conditions such as inflation and exchange rate instability should be considered. Following the example of other similar organisations and the performance and decisions of previous managers in the organisation are also effective factors in the decision to enter the international market. Finally, the study of organisational conditions from management capabilities to financial conditions, experience, and organisational structure are effective factors.

Since the obtained rankings show the importance of each main factors in comparison with each other and the sub-factors were compared to each other in each group, SMEs can plan according to the set priority to formulate their strategies and operational plans.

\section{Which of the Main Decision Factors for Entering the International Market Corresponds to Which of the Decision Options based on the ROT?}

In answer to this question, based on the ROT, there are 5 options to decide to enter the international market. The matrix was formed based on the identified factors in the first question of the research, and the appropriation of the options was

Table 10 Fuzzy and non-fuzzy weights of the country-of-origin sub-factor

\begin{tabular}{|c|c|c|c|c|}
\hline Factors & $\left(\prod_{j=1}^{n} \widetilde{P}_{i j}\right)^{1 / n}$ Geometric mean & $\widetilde{W}$ Fuzzy weight & Non-fuzzy weight & Normal weight \\
\hline G1 & $(0.896,1.024,1.173)$ & $(0.261,0.341,0.447)$ & 0.347 & 0.341 \\
\hline G2 & $(0.831,0.956,1.094)$ & $(0.242,0.318,0.416)$ & 0.324 & 0.318 \\
\hline G3 & $(0.9,1.022,1.162)$ & $(0.263,0.341,0.442)$ & 0.346 & 0.340 \\
\hline$\sum\left(\prod_{j=1}^{n} \widetilde{P}_{i j}\right)^{1 / 2}$ & $(2.627,3.002,3.429)$ & & & \\
\hline
\end{tabular}




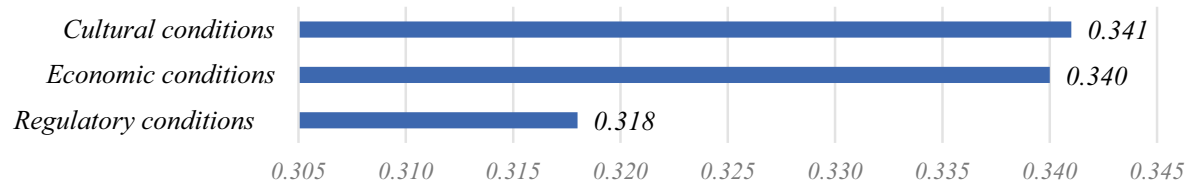

Fig. 6 Weights of sub-criteria of the country of origin

determined with a range of -2 to 2 and was divided into three categories of appropriate, inappropriate, and optional. Since no similar study has been conducted in this field, it is not possible to compare it with previous studies. Based on the alignment matrix, the following results were obtained:

Regarding the geographical conditions of the destination country, it refers to the short geographical distance from the country of origin and the appropriate location in the destination country in the questionnaire. The shorter the distance and the more convenient the location, the more depressing the status of the factor. It is clear that in the case of geographical conditions of the destination country, there is an option to alter the scale and grow the appropriate options. Depending on the desirability of this index for the target country can be used, the abandon/exit option can be used in case of further investigation and in case of undesirableness of this factor for the target country with further investigation.

With regard to the political conditions on both sides of the spectrum, there may be stability or instability, inappropriate or appropriate diplomatic relations. The more favourable the political stability and diplomatic relations with the destination country, the better the option to enter that country. In this case, defer or stage of the political conditions for unfavourable conditions and growth for desirable political conditions are two suitable options for companies. The option of altering the scale can also be used if further consideration and depending on the desirability of the political situation of the target country.

In the case of economic conditions on both sides of the range, there may be stability or instability. The more pleasant the economic stability of the destination country, the better the option to enter that country. In this case, regarding the economic stability of the country, the goal is to change the scale and growth of two suitable options for companies. The option of altering the scale can be used if further study and depending on the desirability of the economic conditions of the target country.

In terms of indicators of regulatory and legal conditions, both sides of the spectrum may exist, supporting or obstructing. The more desirable the regulatory and legal conditions of the destination country and support the entry of international companies, the better the option to enter that country. In this case, regulatory and legal conditions, deferral for unfavourable and obstructive conditions, and growth for favourable and supportive regulatory and legal conditions of the country are the target of two suitable options for companies. The option of altering the scale can also be used if further investigation and depending on the desirability of the regulatory and legal conditions of the target country. 


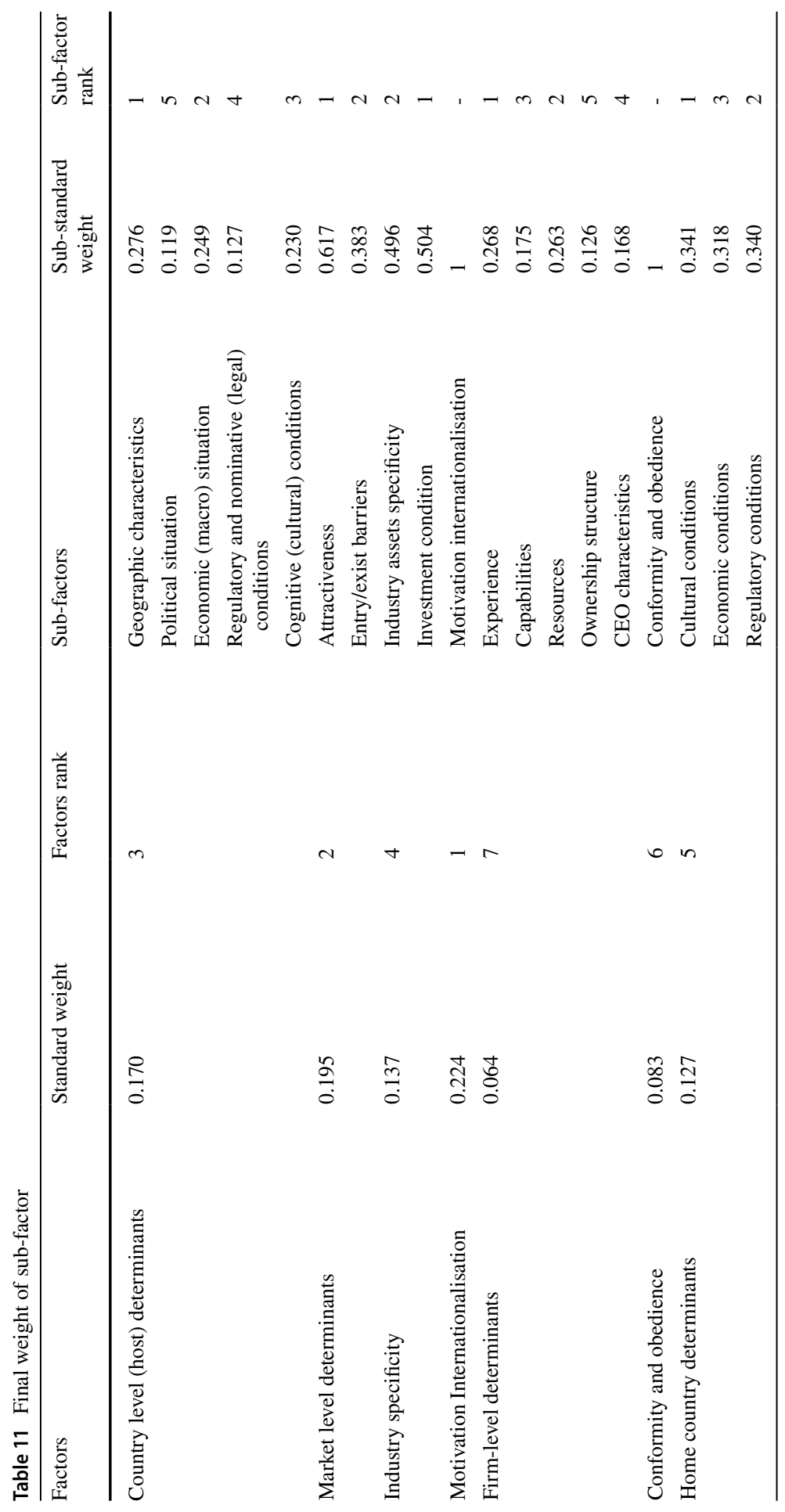




\begin{tabular}{|c|c|c|c|c|c|c|c|c|c|c|c|c|c|c|}
\hline \multirow[b]{2}{*}{ Factors } & \multirow{2}{*}{ 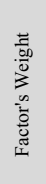 } & \multirow{2}{*}{ 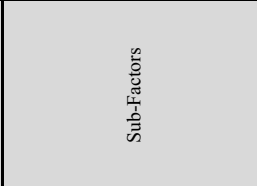 } & \multirow{2}{*}{ 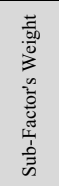 } & \multirow{2}{*}{ 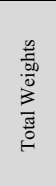 } & \multicolumn{2}{|c|}{$\begin{array}{l}\text { Defer or } \\
\text { stage }\end{array}$} & \multicolumn{2}{|c|}{$\begin{array}{c}\text { Abandon/e } \\
\text { xit }\end{array}$} & \multicolumn{2}{|c|}{ Switch } & \multicolumn{2}{|c|}{$\begin{array}{c}\text { Alter scale } \\
\text { (expand/con } \\
\text { tract) }\end{array}$} & \multicolumn{2}{|c|}{ Grow } \\
\hline & & & & & $\ll$ & $\stackrel{\infty}{\Leftrightarrow}$ & 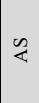 & $\sum_{\leftarrow}^{\infty}$ & \& & $\sum_{1}^{\infty}$ & $\frac{\infty}{4}$ & $\sum_{\leftarrow}^{\infty}$ & 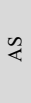 & $\sum_{\leftarrow}^{\infty}$ \\
\hline \multirow{5}{*}{$\begin{array}{l}\text { Country level (host) } \\
\text { determinants }\end{array}$} & \multirow{5}{*}{0.17} & Geographic characteristics & 0.276 & 0.047 & -2 & -0.09 & 0 & 0 & -1 & -0.05 & 1 & 0.05 & 2 & 0.09 \\
\hline & & Political situation & 0.119 & 0.02 & 2 & 0.04 & -1 & -0.02 & -2 & -0.04 & 0 & 0 & 1 & 0.02 \\
\hline & & Economic (macro) situation & 0.249 & 0.042 & -1 & -0.04 & -2 & -0.09 & 0 & 0 & 1 & 0.04 & 2 & 0.09 \\
\hline & & \begin{tabular}{|l|} 
Regulatory and Nominative \\
(Legal) conditions \\
\end{tabular} & 0.127 & 0.022 & 2 & 0.04 & -1 & -0.02 & -2 & -0.04 & 0 & 0 & 1 & 0.02 \\
\hline & & Cognitive (cultural) conditions & 0.23 & 0.039 & -1 & -0.04 & -2 & -0.08 & 2 & 0.08 & 1 & 0.04 & 0 & 0 \\
\hline \multirow{2}{*}{$\begin{array}{l}\text { market level } \\
\text { determinants }\end{array}$} & \multirow{2}{*}{0.20} & Attractiveness & 0.617 & 0.12 & -2 & -0.24 & -1 & -0.12 & 0 & 0 & 1 & 0.12 & 2 & 0.24 \\
\hline & & Entry/ Exist barriers & 0.383 & 0.075 & 1 & 0.08 & 0 & 0 & -2 & -0.15 & 2 & 0.15 & -1 & -0.08 \\
\hline \multirow{2}{*}{ Industry specificity } & \multirow{2}{*}{0.14} & Industry assets specificity & 0.496 & 0.068 & -2 & -0.14 & 1 & 0.07 & 2 & 0.14 & 0 & 0 & -1 & -0.07 \\
\hline & & Investment condition & 0.504 & 0.069 & -2 & -0.14 & -1 & -0.07 & 0 & \begin{tabular}{|l|}
0 \\
\end{tabular} & 2 & 0.14 & 1 & 0.07 \\
\hline \begin{tabular}{|l|} 
Motivation \\
Internationalisation \\
\end{tabular} & 0.22 & Motivation Internationalisation & 1 & 0.224 & -1 & -0.22 & -2 & -0.45 & 2 & 0.45 & 1 & 0.22 & 0 & 0 \\
\hline \multirow{5}{*}{$\begin{array}{l}\text { Firm-level } \\
\text { determinants }\end{array}$} & \multirow{5}{*}{0.06} & Experience & 0.268 & 0.017 & -1 & -0.02 & -2 & -0.03 & 2 & 0.03 & 1 & 0.02 & 0 & 0 \\
\hline & & Capabilities & 0.175 & 0.011 & -2 & -0.02 & -1 & -0.01 & 0 & \begin{tabular}{|l|}
0 \\
\end{tabular} & 2 & 0.02 & 1 & 0.01 \\
\hline & & \begin{tabular}{|l|} 
Resources \\
\end{tabular} & 0.263 & 0.017 & -2 & -0.03 & 2 & 0.03 & 0 & 0 & 1 & 0.02 & -1 & -0.02 \\
\hline & & Ownership structure & 0.126 & 0.008 & 2 & 0.02 & 1 & 0.01 & 0 & 0 & 0 & 0 & 1 & 0.01 \\
\hline & & CEO characteristics & 0.168 & 0.011 & 0 & 0 & -1 & -0.01 & 2 & 0.02 & 1 & 0.01 & 0 & 0 \\
\hline $\begin{array}{l}\text { Conformity and } \\
\text { obedience }\end{array}$ & 0.08 & Conformity and obedience & 1 & 0.083 & 2 & 0.17 & 1 & 0.08 & 0 & 0 & -2 & -0.17 & -1 & -0.08 \\
\hline \multirow{3}{*}{$\begin{array}{l}\text { Home country } \\
\text { determinants }\end{array}$} & \multirow{3}{*}{0.13} & Cultural conditions & 0.341 & 0.043 & 2 & 0.09 & 0 & 0 & 1 & 0.04 & -1 & -0.04 & -2 & -0.09 \\
\hline & & Economic conditions & 0.318 & 0.04 & 1 & 0.04 & 2 & 0.08 & 0 & 0 & -2 & -0.08 & -1 & -0.04 \\
\hline & & Regulatory conditions & 0.34 & 0.043 & 1 & 0.04 & 2 & 0.09 & 0 & 0 & -2 & -0.09 & -1 & -0.04 \\
\hline
\end{tabular}

Table 12 Decision options matrix

In the case of cultural distance, there may be two sides. When the cultural distance is large and people are risk-averse, the two options of change and scale change are two suitable options for companies.

It is predictable that the organisation will enter the international market in search of a market and a potential consumer. When the conditions and attractiveness of the target market are high, scale change and growth are two suitable options for companies. The option of change can be used if further consideration and depending on the desirability of the target market attractiveness.

In the case of barriers to entry and exit, alter the scale and defer are the two best options for companies. In case of further investigation and depending on the severity of barriers to entry and exit to the target market, a release option is a suitable option.

In the case of the industry-specific characteristics, since specific properties can be a major barrier to entering the international market, the options of abandonment and change are suitable for companies. In case of further study and depending on the costs of technology, research, and development, etc., the option of scaling can also be a suitable option, but it needs to be examined more carefully.

In terms of the investment condition, the lower the required investment and the sooner the return, the change of scale and growth are two suitable options for companies depending on the desirability of this factor. The option of change can be used if further investigation and depending on the desirability of investment conditions.

Turning to internationalisation motivations, the option of change and alter the scale are two suitable options for companies depending on the desirability of this factor. But it is not because of these benefits alone that a final decision can be made, and the growth option can be explored further depending on the desirability of the benefits of internationalisation. 
Regarding the experience, a scaling option is a suitable option for companies depending on the desirability of this factor. When the experience of being present in the growth option can also be used with further consideration and depending on other conditions.

Regarding organisational capabilities and competencies, the higher the capabilities and competencies of organisations, they can change the scale and growth of two suitable options for companies depending on the desirability of this factor if other conditions are appropriate. The option of change can be used by further examination and depending on other conditions and the degree of desirability of organisational capabilities and competencies.

According to the financial condition of the release company, it is a suitable option for companies for undesirable conditions and for suitable conditions to change the scale depending on the desirability of this factor. The option of change can also be used by further examination and depending on other conditions and the degree of desirability of the financial condition.

Regarding the ownership structure, depending on the type of ownership and their conditions, the options of growth, postponement, and release can be used, and the option of change and scale change needs further consideration and other conditions.

\section{Implications}

\section{Implications for Theory}

Real options theory has a lot of potential for developing the rationality of the present business environment. The study highlighted the major factors in respect of the decision-making in the context of SMEs internationalisation. It presents an opportunity for academicians working in the domain of internationalisation research to consider the impact of the strategic factors, in general, with an understanding of the potential impact of ROT as a strong method of decision making. Since ROT is in the initial phase of adoption, the present study contributes in terms of bringing forth perceived challenges and issues in the process of international market entry. The study contributes to the organisation and innovation literature in terms of stating the potential benefits of embedding ROT as a part of a larger decision-making system in the firm. Hence, it advances an understanding of how ROT can drive a change in the decision-making process of an organisation. Thus, it holds implications for scholars engaged in the study of SMEs internationalisation. From the perspective of decision-making studies, it gives an indication of how the use of ROT can expand the information available and needed in a company's decision-making. Additionally, it furthers an understanding of effective factors on decision-making from the lens of real options theory.

\section{Implications for Practice}

Our study demonstrates the decision-making process of SMEs entering international markets. Decisions about international entry mode strategies and identification of 
effective factors are difficult, falling initially under the purview of international marketing managers. The main problem relates to the ability to collect all the information needed to produce the most profitable decision. The managerial implications discussed here relate to the importance of a long-term approach when internationalisation. How companies learn to find, analyse, and use present information is largely related to prior and experiential knowledge. In the case of SMEs internationalisation, this often means identification of effective factors for decision-making, given that international experience accumulates from learning by doing and that the required knowledge may not exist within the company.

Thus, managers need to learn from partners or recruit wisely to acquire the necessary knowledge. Moreover, ROT offers SMEs manager alternatives, which, as much as possible, lower risk, so, this gives some support to the use of ROT for achieving above-average performance. Managers could use options in the foreign market by entering through a low investment mode or using other entry modes. They could enter a market through exporting and wait for the right time to expand the investment. Meanwhile, they would have the option of abandoning the investment project without incurring high costs. This could result in superior performance. At the same time, it would help managers to exploit opportunities in different markets without having to collect all the information, a particularly important benefit when resources are tight.

\section{Limitations and Future Offers}

Beyond a shadow of a doubt, researchers face limitations and problems in conducting their research that may affect the results of the research. Recognizing these limitations makes it possible to better interpret the results of research and also to improve the quality of future research. This research has various limitations. First, given its qualitative nature, we can only make analytical generalisations. Therefore, we would encourage future researchers with larger samples and other countries to find more precise factors. Second, interviews with more interviewees (e.g., with marketing managers, executive managers, and SMEs CEOs) could identify any information bias among CEOs, other members of management, and SMEs owners, better validating our study. Third, the SMEs analysed are of different sizes and operating in different sectors. There could be a size and context bias in entry mode selection, and we would recommend future studies take this into account. For instance, a follow-up quantitative study could control the effect of SMEs size on the relationship between rationality in the decision approach and performance. This study also has witnessed limitations which are discussed below.

\section{Lack of Proper Cooperation of Experts in Answering the Questionnaires}

There may be intrusive variables that affect the identification of factors that are the researcher's inability to control unwanted variables. 
Since the results of the research are the result of a survey of (SMEs) in Isfahan, caution should be exercised in generalizing the results to other organisations.

The results of the research are limited to the research period so that generalizing the results is specially related to that period.

Based on the title of the research and its findings, the following research suggestions are provided for future researchers:

Since the results are limited to the opinions of (SMEs) in Isfahan, the results can be different in other cities. Therefore, it is suggested that this research be repeated in other cities and in large companies, and its results are compared with the results of the present study.

Given that decision options may have been selected based on real options theory, future research could include other possible options in the selection matrix.

Funding Open access funding provided by Università degli Studi di Napoli Federico II within the CRUICARE Agreement.

\section{Declarations}

Ethics approval All procedures performed in studies involving human participants were in accordance with the ethical standards of the institutional and/or national research committee and with the 1964 Helsinki declaration and its later amendments or comparable ethical standards.

Consent to Participate Informed consent was obtained from all individual participants included in the study.

Consent for Publication The authors give their consent for the publication of identifiable details, to be published in the Journal of the Knowledge Economy.

Conflict of Interest The authors declare no competing interests.

Open Access This article is licensed under a Creative Commons Attribution 4.0 International License, which permits use, sharing, adaptation, distribution and reproduction in any medium or format, as long as you give appropriate credit to the original author(s) and the source, provide a link to the Creative Commons licence, and indicate if changes were made. The images or other third party material in this article are included in the article's Creative Commons licence, unless indicated otherwise in a credit line to the material. If material is not included in the article's Creative Commons licence and your intended use is not permitted by statutory regulation or exceeds the permitted use, you will need to obtain permission directly from the copyright holder. To view a copy of this licence, visit http://creativecommons.org/ licenses/by/4.0/.

\section{References}

Agarwal, S., \& Ramaswami, S. (1992). Choice of foreign market entry mode: Impact of ownership, location, and internalization factors. Journal of International Business Studies, 23(1), 1-27.

Ahi, A., Baronchelli, G., Kuivalainen, O., \& Piantoni, M. (2017). International market entry: How do small and medium-sized enterprises make decisions? Journal of International Marketing, 25(1), 1-21.

Alayo, M., Maseda, A., Iturralde, T., \& Arzubiaga, U. (2019). Internationalisation and entrepreneurial orientation of family SMEs: The influence of the family character. International Business Review, 28, 48-59. 
Altun, İ. (2017). Determinants of the export performance of SMEs: Comparative analysis of Türkish SMEs exporting to Middle East and European regions. International Journal of Business and Social Science, 8(3), 75-88.

Ambos, B., \& Håkanson, L. (2014). The concept of distance in international management research. Journal of International Management, 20(1), $1 \mathrm{e} 7$.

Ambos, T. C., \& Ambos, B. (2009). The impact of distance on knowledge transfer effectiveness in multinational corporations. Journal of International Management, 15(1), 1e14.

Behar, R. (2014). The vulnerable observer: Anthropology that breaks your heart. Beacon Press.

Berry, H., Guillen, M. F., \& Zhou, N. (2010). An institutional approach to cross national distance. Journal of International Business Studies, 41(9), 1460e1480.

Beugelsdijk, S., Kostova, T., Kunst, V. E., Spadafora, E., \& Van Essen, M. (2018). Cultural distance and firm Internationalisation: A meta-analytical review and theoretical implications. Journal of Management, 44(1), 89e130.

Boeh, K. K., \& Beamish, P. W. (2012). Travel time and the liability of distance in foreign direct investment: Location choice and entry mode. Journal of International Business Studies, 43(5), 525e535.

Borgersen, T. A. (2005). The problem of exporting for developing countries SMEs-market entry costs, exchange rate shocks and the capital structure of firms. The Journal of African Policy Studies, 10(1), 1-19.

Brouthers, K. D., Brouthers, L. E., \& Werner, S. (2008). Real options, international entry mode choice and performance. Journal of Management Studies, 45, 936-960.

Calabrese, M., Iandolo, F., Caputo, F., \& Sarno, D. (2018). From mechanical to cognitive view: The changes of decision making in business environment. Social Dynamics in a Systems Perspective (pp. 223-240). Springer.

Canestrino R., Magliocca P. (2019). Dal knowledge management ai knowledge ecosystem, n. 10, 2019, ESI, Napoli, (ISBN: 978-88-495-4114-4).

Canestrino R., Magliocca P. (2016). Transferring knowledge through cross-border communities of practice in Buckley S., Majewski G.; Giannakopoulos A. (2016), Organisational knowledge facilitation through communities of practice in emerging markets, IGI - Global, 2016, pp. 1-30 (ISBN13: 9781522500131; ISBN10: 1522500138; EISBN13: 9781522500148; https://doi.org/10.4018/ 978-1-5225-0013-1

Caputo, F., \& Evangelista, F. (2019). Information sharing and cognitive involvement for sustainable workplaces. In Corporate social responsibility: Concepts, methodologies, tools, and applications. IGI Global. 1403-1420.

Caputo, F., Soto-Acosta, P., Chiacchierini, C., Mazzoleni, A., \& Passaro, P. (2020). Smashing local boundaries for sustain companies' innovativeness: The role of international R\&D teams. Journal of Business Research. https://doi.org/10.1016/j.jbusres.2020.04.062

Casali, G. L., \& Perano, M. (2020). Forty years of research on factors influencing ethical decision making establishing a future research agenda. Journal of Business Research. https://doi.org/10.1016/j.jbusres. 2020.07.006

Caves, R. E. \& Mehra, S. K. (1986). Entry of foreign multinationals into U.S. manufacturing industries. In E. Michael, \& Porter (Eds.), Competition in global industries. Boston: Harvard Business Press.

Cavusgil, S. T. (1985). "Guidelines for export market research', Business Horizons, NovemberDecember, 28(6), 27-33.

Chan, C. M., \& Makino, S. (2007). Legitimacy and multi-level institutional environments: Implications for foreign subsidiary ownership structure”. Journal of International Business Studies, 38, 621-638.

Chawla, S. K., Khanna, D., \& Chen, J. (2010). Are small business critical success factors same in different countries. SIES Journal of Management, 7, 1-12.

Chen, S. F. S. (2008). The motives for international acquisitions: Capability procurements, strategic considerations, and the role of ownership structures. Journal of International Business Studies, 39(3), 454-471.

Child, J., \& Hsieh, L. H. Y. (2014). Decision mode, information and network attachment in the internationalisation of SMEs: A configurational and contingency analysis. Journal of World Business, 49(4), 598-610.

Collins, C. S., \& Cooper, J. E. (2014). Emotional intelligence and the qualitative researcher. International Journal of Qualitative Methods, 13(1), 88-103.

Copeland, T., \& Howe, K. M. (2021). Real options and strategic decisions. (Strategic Management). Strategic Finance, 83(10), 2002, p. 8+. Accessed 6 Feb. 
Csapi, V. (2019). How real option theory has gained space in research and practice-An overview of the last four decades. International Research Journal of Finance and Economics, 171, 86-95.

Czinkota, M. R., Ronkainen, I. A., \& Moffett, M. H. (2007). International Business, 4th edition, The Dryden Press, 408-427.

Del Giudice, M., Arslan, A., Scuotto, V., \& Caputo, F. (2017). Influences of cognitive dimensions on the collaborative entry mode choice of small-and medium-sized enterprises. International Marketing Review, 34(5), 652-673.

Dell'Anno, D., Evangelista, F., \& Del Giudice, M. (2018). Internationalisation of science-based start-ups: Opportunity or requirement? Journal of the Knowledge Economy, 9(2), 649-664.

Demirbag, M., Glaister, K. W., \& Tatoglu, E. (2007). Institutional and transaction cost influences on MNEs' ownership strategies of their affiliates: Evidence from an emerging market. Journal of World Business, 42(4), 418-434.

Denison, D. R., Dutton, J. E., Kahn, J. A., \& Hart, S. L. (1996). Organisational context and the interpretation of strategic issues: Anoteon CEOs' interpretations of foreign investment. Journal of Management Studies, 33, 453-474.

De Soto-Camacho, E. G., \& Álvarez-Torrescusa, M. (2018). Choice of entry mode into the internationalisation process by dominant Spanish hotel chains. Enlightening Tourism, 8(2), 128-157. https://doi. org/10.33776/et.v8i2.3455

Díez-Vial, I., \& Fernández-Olmos, M. (2013). Internal resources, local externalities and export performance: An application in the Iberian ham cluster. Journal of Management \& Organisation, 19(4), $478-497$.

Dow, D., \& Karunaratna, A. (2006). Developing a multidimensional instrument to measure psychic distance stimuli. Journal of International Business Studies, 37(5), 578e602.

Driouchi, T., \& Bennett, D. J. (2011). Real options in multinational decision-making: Managerial awareness and risk implications". Journal of World Business, 46(2), 205-219.

Elbanna, S., \& Child, J. (2007). The influence of decision, environmental and firm characteristics on the rationality of strategic decision-making. Journal of Management Studies, 44(4), 561-591.

Engwall, L. (Ed.). (1984). Uppsala contributions to business research. Acta Universatitas Upsaliensis.

Evers, N., \& O'Gorman, C. (2011). Improvised internationalisation in new ventures: The role of prior knowledge and networks. Entrepreneurship and Regional Development, 23(7/8), 549-574.

Falk, M. (2014). Background study for the European competitiveness report drivers of SME internationalisation: Implications for firm growth and competitiveness.

Felzensztein, C., Ciravegna, L., Robson, P., \& Amorós, E. (2015). Networks, entrepreneurial orientation, and Internationalisation scope: Evidence from Chilean SMEs. Journal of Small Business Management, 53(S1), 145-160.

Fife, W. (2005). Doing fieldwork: Ethnographic methods for research in developing countries and beyond. Springer.

Freeman, S. (2012). 'Born global firms' use of networks and alliances: A social dynamic perspective,' in Mika Gabrielsson and V.H. Manek Kirpalani (eds), Handbook of research on born globals, Cheltenham, UK and Northampton, MA, USA: Edward Elgar Publishing.

Gabrielsson, P., \& Gabrielsson, M. (2013). A dynamic model of growth phases and survival in international business-to-business new ventures: The moderating effect of decision-making logic. Industrial Marketing Management, 42(8), 1357-1373.

Gao, Z., Qu, Y., \& Zhang, Z. (2019). The role of networks in SMEs' Internationalisation. A perception from the emerging Asian market under the trend of deglobalization. Jonkoping University.

Ghemawat, P. (2001). Distance still matters. The hard reality of global expansion. Harvard Business Review., 79, 137-142.

Gilmore, A., Carson, D., \& Grant, K. (2001). SME marketing in practice. Marketing Intelligence \& Planning, 19(1), 6-11.

Guest, G., Bunce, A., \& Johnson, L. (2006). How many interviews are enough? An experiment with data saturation and variability. Field Methods, 18(1), 59-82.

Harzing, A. W. (2002). Acquisitions versus Greenfield investments: International strategy and management of entry modes. Strategic Management Journal, 23, 211-227.

Hawamdeh, S., \& Raigangar, V. (2014). Qualitative interviewing: Methodological challenges in Arab settings. Nurse Researcher, 21(3), 27-31.

Hiebl, M. R. W. (2014). Upper echelons theory in management accounting and control research. Journal of Management Control, 24(3), 223-240. 
Hitt, M. A., Hoskisson, R. E., Kim, H. (1997). International diversification: Effects on innovation and firm performance in product-diversified firms. The Academy of Management Journal, 40(4), 767-798.

Holmvall, L., \& Åkesson, A. (2010). Export\& Import- att göra internationella affärer, Andra upplagan, Liber $A B$.

Pham, T. H. S. (2019). Effectuation and causation are drivers toward Internationalisation success of SMEs, Lappeenranta University of Technology School of Business and Management, Master's Degree Programme in International Marketing Management.

Joensuu-Salo, S., Sorama, K., Viljamaa, A., \& Varamäki, E. (2018). Firm performance among internationalized SMEs: The interplay of market orientation, Marketing Capability and Digitalization. Administrative sciences, 8(31), 1-13.

Johanson, J., \& Vahlne, J. E. (1977). The internationalisation process of the firm-A model of knowledge development and increasing foreign market commitments. Journal of International Business Studies, 8, 23-32. https://doi.org/10.1057/palgrave.jibs.8490676

Kaur, S., Gupta, S., Singh, S., \& Perano, M. (2019). Organisational ambidexterity through global strategic partnerships: A cognitive computing perspective, technological forecasting and social change (ISSN 0040-1625), 145, pp. 43-54. https://doi.org/10.1016/j.techfore.2019.04.027

Kester, W. C. (1984). Today's options for tomorrow's growth. Harvard Business Review, 62, 153-160.

Khaidher, K., Safi, W., \& Eneizan, B. (2019). SMEs as a Strategic Choice for Development Case Study of Algeria. International Journal of Academic Research in Business and Social Sciences, 9(3), 87-101.

Khatri, N., \& Ng, H. A. (2000). The role of intuition in strategic decision making. Human Relations, 53(1), 57-86.

Kim, J. J., \& Hemmert, M. (2016). What drives the export performance of small and medium-sized subcontracting firms? A study of Korean manufacturers. International Business Review, 25(2), 511-521.

Knight, G., \& Daekwan, K. (2009). International business competence and the contemporary firm. Journal of International Business Studies, 40(2), 255-273.

Kogut, B., \& Singh, H.(1988). The effect of national culture on the choice of entry mode. Journal of International Business Studies, 19(3), 411-432.

Kuivalainen, O., Sundqvist, S., Saarenketo, S., \& McNaughton, R. (2012). Internationalisation patterns of small and medium-sized enterprises. International Marketing Review, 29, 448-465.

Långbacka, Anna. (2019). A study of Finnish companies entering the South Korean market. Master's Thesis International Business Management, Arcada.

Laufs, K., \& Schwens, C. (2014). Foreign market entry mode choice of small and medium-sized enterprises: A systematic review and future research agenda. International Business Review, 23(6), 1109-1126.

Lecerf, M., \& Omrani, N. (2020). SMEs Internationalisation: The impact of information technology and innovation. Journal of the Knowledge Economy, 11(2), 805-824.

Maekelburger, B., Schwens, C., \& Kabst, R. (2012). Asset specificity and foreign market entry mode choice of small and medium-sized enterprises: The moderating influence of knowledge safeguards and institutional safeguards. Journal of International Business Studies, 43, 458-476.

Majocchi, A., Mayhofer, U., \& Bacchiocchi, E. (2005). Firm size, business experience and export intensity in SMEs: A longitudinal approach to a complex relationship. International Business Review, 14(6), 719-738.

Manolova, T. S., Manev, I. M., \& Gyoshev, B. S. (2010). In good company: The role of personal and inter-firm networks for new-venture Internationalisation in a transition economy. Journal of World Business, 45(3), 257-265.

Markman, G. D., Gianiodis, G. P., Payne, T., Tucci, C., Filatotchev, I., Kotha, R., \& Gedajlovic, E. (2019). The who, where, what, how and when of market entry. Journal of Management Studies, 56(7), 1241-1259.

McGuinness, N. W. (1981). The influence of product characteristics on the export performance of new industrial products. Journal of Marketing, 45(2), 110-122.

Moalla, E., \& Mayrhofer, U. (2020). How does distance affect market entry mode choice? Evidence from French companies. European Management Journal, 38(1), 135-145.

Morgan, N. A., Katsikeas, C. S., \& Vorhies, D. W. (2012). Export marketing strategy implementation, export marketing capabilities, and export venture performance. Journal of the Academy of Marketing Science, 40(2), 271-289. 
Nowinski, W., \& Rialp, A. (2013). Drivers and strategies of international new ventures from a Central European transition economy. Journal for East European Management Studies, 18(2), 191-231.

Nummela, N., Saarenketo, S., Jokela, P., \& Loane, S. (2014). Strategic decision-making of a born global: A comparative study from three small open economies. Management International Review, 54(4), 527-550.

Nurcholis, L. (2020). How to improve internationalisation strategy based on market characteristics, culture understanding, and knowledge management: The mediating effect of management behaviour. Journal of the Knowledge Economy, 1-24.

Oviatt, B. M., \& McDougall, P. P. (1995). Global start-ups: Entrepreneurs on a worldwide stage. Academy of Management Executive, 9(2), 30-43.

Papadakis, V. M., \& Barwise, P. (2002). How much do CEOs and top managers matter in strategic decision-making? British Journal of Management, 13(1), 83-95.

Pattnaik, C., Choe, S., \& Singh, D. (2014). Impact of host country institutional context on subsidiary performance. Management Decision, 53(1), 198e220.

Pinho, J. C. (2007). The impact of ownership-location-specific advantages and managerial characteristics on SMEs foreign entry mode choices. International Marketing Review, 24(6), 715-734.

Ragozzino, R. (2009). The effects of geographic distance on the foreign acquisition activity of US firms. Management International Review, 49, 509. https://doi.org/10.1007/s11575-009-0006-7

Ramón-Llorens, M. C., García-Meca, E., \& Duréndez, A. (2017). Influence of CEO characteristics in family firm's Internationalisation. International Business Review, 26(4), 786-799.

Raymond, L., \& St-Pierre, J. (2011). Strategic capability configurations for the Internationalisation of SMEs: A study in equifinality. International Small Business Journal, 31, 82-102.

Rundh, B. (2007). International marketing behaviour amongst exporting firms. European Journal of Marketing, 41(1/2), 181-198.

Sampson, G. P., \& Snape, R. H. (1985). Identifying the issues in trade in services. The World Economy, $8(2), 171-183$.

Schwartz, S. H. (1994). Beyond individualism/collectivism: New cultural dimensions of values. In U. Kim, H. C. Triandis, Ç. Kâğitçibaşi, S.-C. Choi, \& G. Yoon (Eds.), Individualism and collectivism: Theory, method, and applications, Cross-cultural research and methodology series, Sage Publications, Inc. 18, 85-119.

Schweizer, R. (2012). The internationalisation process of SMEs: A muddling-through process. Journal of Business Research, 65, 745-751.

Scuotto, V., Del Giudice, M., Shlomo, T., MesseniPetruzzelli, A., \& Chang, V. (2020). International social SMEs in emerging countries: Do governments support their international growth? Journal of World Business, 55, 5. https://doi.org/10.1016/j.jwb.2019.05.002

Sharma, R., Mithas, S., \& Kankanhalli, A. (2014). Transforming decision-making processes: A research agenda for understanding the impact of business analytics on organisations. European Journal of Information Systems, 23(4), 433-441.

Shieh, B. L., \& Wu, T. C. (2012). Equity-based entry modes of the Greater Chinese. Economic area's foreign direct investments in Vietnam. International Business Review, 21(3), 508-517.

Sinclair, M., \& Ashkanasy, N. M. (2005). Intuition: Myth or a decision-making tool? Management Learning, 36(3), 353-370.

Sousa, C. M. P., Martínez-López, F. J., \& Coelho, F. (2008). The determinants of export performance: A review of the research in the literature between 1998 and 2005. International Journal of Management Reviews, 10(4), 343-374.

Trigeorgis, L., \& Reuer, J. J. (2017). Real options theory in strategic management. Strategic Management Journal, 38, 42-63.

Welch, L., \& Luostarinen, R. (1988). Internationalisation: Evolution of a concept. Journal of General Management Studies, 14(2), 36-64.

Wu, Z., \& Salomon, R. (2016). Does imitation reduce the liability of foreignness? Linking distance, isomorphism, and performance. Strategic Management Journal, 37(12), 2441e2462.

Yu, C. M., \& Ito, K. (1988). Oligopolistic reaction and foreign direct investment: The case of the U.S. tire and textile industries. Journal of International Business Studies, 19(Fall), 449-460.

Zachary, M. A., Gianiodis, P. T., Payne, G. T., \& Markman, G. D. (2015). Entry timing: Enduring lessons and future directions. Journal of Management, 41, 1388-1415.

Zaki, A. M., Edwards, D., \& El-Gohary, H. (2015). A theoretical examination of SMEs internationalisation in a globalised business environment: An eye on the future. International Journal of Customer Relationship Marketing and Management, 6(4), 1-22. 
Zheng, C., Morrison, M., \& O’Neill, G. (2006). An empirical study of high performance HRM practices in Chinese SMEs. The International Journal of Human Resource Management, 17(10), $1772-1803$.

Zou, S., \& Stan, S. (1998). The determinants of export performance: A review of the empirical literature between 1987 and 1997. International Marketing Review, 15(5), 333-356.

Publisher's Note Springer Nature remains neutral with regard to jurisdictional claims in published maps and institutional affiliations.

\section{Authors and Affiliations}

\section{Jamshid Alinasab ${ }^{1}$. Seid Mohammad Reza Mirahmadi ${ }^{2} \cdot$ Hassan Ghorbani $^{1}$.} Francesco Caputo ${ }^{3}$

Jamshid Alinasab

Jamshid.Alinasab@gmail.com

1 Management Department, Mobarakeh Branch, Islamic Azad University, Isfahan, Iran

2 Management Department, Dolatabad Branch, Islamic Azad University, Isfahan, Iran

3 Department of Economics, Management, and Institutions (DEMI), University of Naples "Federico II", Naples, Italy 